\title{
A new miniature species of Odontocharacidium (Characiformes: Crenuchidae) from the Río Orinoco a basin, Venezuela
}

Correspondence: Elizabeth K. de Queiroz Rodrigues elizabethbio3@gmail.com

Submitted November 6, 2019

Accepted May 6, 2020 by George Mattox

Epub Jun 26, 2020

Online version ISSN 1982-0224 Print version ISSN 1679-6225

Neotrop. Ichthyol.

vol. 18, no. 2, Maringá 2020

\author{
${ }^{-}$Elizabeth Kathleen de Queiroz Rodrigues ${ }^{1,2}$ and \\ ${ }^{\circ}$ Andre L. Netto-Ferreira ${ }^{3}$
}

A new species of Odontocharacidium is described from the upper Río Orinoco basin, in Venezuela. The new species is distinguished from its only congener, Odontocharacidium aphanes, by the presence of: the antorbital, the parietal branch of the supraorbital laterosensory canal, the postcleithrum 1, the conspicuous bars extending ventrally below the middle portion of the body posteriorly, and two dark round blotches at the tip of the caudal peduncle. With the recognition of an additional species of Odontocharacidium the diagnostic characters of the genus and the variability in the number of maxillary teeth in specimens are discussed.

Keywords: Characidiinae, Miniaturization, Neotropics, Taxonomy, Teleostei.

Uma nova espécie de Odontocharacidium é descrita para a bacia do alto rio Orinoco, na Venezuela. A nova espécie se distingue da sua única congênere, Odontocharacidium aphanes, pela presença: do antorbital, do ramo parietal do canal látero-sensorial supraorbital, do pós-cleitro 1 , de barras conspícuas estendendo-se ventralmente à porção média do corpo e de duas manchas escuras e arredondadas na margem distal do pedúnculo caudal. Com o reconhecimento de uma espécie adicional de Odontocharacidium, são discutidos os caracteres diagnósticos do gênero e a variação no número de dentes maxilares nos espécimes.

Palavras-chave: Characidiinae, Miniaturização, Neotrópico, Taxonomia, Teleostei.

\footnotetext{
1 Programa de Pós-Graduação em Zoologia da Universidade Federal do Pará (UFPA), Instituto de Ciências Biológicas, Campus Básico, R. Augusto Côrrea, 01, Guamá, 66075-110 Belém, PA, Brazil.

2 Grupo de Pesquisa em Ecologia e Biologia de Peixes, Instituto de Desenvolvimento Sustentável Mamirauá (IDSM), Estrada do Bexiga, 2584, Fonte Boa, 69553-225 Tefé, AM, Brazil. elizabethbio3@gmail.com (corresponding author).

3 Laboratório de Ictiologia, Departamento de Zoologia, Instituto de Biociências, Universidade Federal do Rio Grande do Sul (UFRGS), Av. Bento Gonçalves, 9500, Agronomia, 91501-970 Porto Alegre, RS, Brazil. alnferreira@gmail.com.
} 


\section{INTRODUCTION}

Odontocharacidium Buckup is a miniature representative of the Crenuchidae, a moderately diverse Neotropical family containing 95 valid species distributed in 11 genera and two subfamilies (Fricke et al., 2020). The genus was erected to allocate its type species Klausewitzia aphanes Weitzman, Kanazawa as it was considered more closely related to the also miniature genera Microcharacidium Buckup and Elachocharax Myers, than to K. ritae Géry (the type species of Klausewitzia) in the sole phylogenetic study for the Crenuchidae (Buckup, 1993a). That close relationship between the three genera (clade EMO) was based on the lack of the parietal branch of supraorbital laterosensory canal; the absence of uroneurals; the presence of only conical teeth in both jaws; the incomplete lateral line; and the presence of a pair of dark blotches, located at the base of the dorsal and ventral caudal-fin lobes (Buckup, 1993a).

Odontocharacidium was diagnosed from the other crenuchids by: 1) absence of posttemporal; 2) absence of the supratemporal laterosensory canal; 3) absence of the pterotic laterosensory canal, and 4) pterotic, parietal and sphenotic lacking dermal portions between the semicircular canals, with the posttemporal fossa limited anteriorly by the sphenotic; 5) absence of postcleithrum 1 (Buckup, 1993b). In addition to these characters, the genus can be recognized by the lack of conspicuous dark pigmentation on the median portions of the pectoral and pelvic fin-rays, and the lack of a conspicuous black blotch on the posterior margin on the adipose fin (Buckup, van der Sleen, 2018). To date, the genus included only its type species, Odontocharacidium aphanes (Weitzman, Kanazawa) from the rio Negro in the Amazon basin (Weitzman, Kanazawa, 1977), but during a revisionary study of the genus, a new species from the Río Orinoco in Venezuela was detected among museum samples, and is described herein.

\section{MATERIAL AND METHODS}

Counts and measurements follow Buckup (1993b). Measurements were made from photographs of the left side of specimens, with aid of the software Axion Vision 4.8. All measurements are presented as proportions of standard length (SL), except for subunits of the head, which are presented as proportions of the head length (HL). The values for each meristic data in the description are followed by their frequency in parentheses with an asterisk indicating the values for the holotype. Counts of vertebrae, supraneurals, branchiostegal rays, and teeth were obtained from cleared and stained (c\&s) specimens prepared according to Taylor, Van Dyke (1985). Vertebrae of the Weberian apparatus were counted as four precaudal elements, and the fused PU1+U1 of the caudal region as a single element. Specimens were sexed macroscopically through a small incision on the right side of the body for gonad inspection.

Institutional abbreviations are Academy of Natural Sciences of the Drexel University (ANSP), Field Museum of Natural History (FMHN), Instituto Nacional de Pesquisas da Amazônia (INPA), Laboratório de Biologia e Genética de Peixes (LBP), Museo de Historia Natural La Salle (MHNLS), Museu Paraense Emílio Goeldi (MPEG), Museu de Zoologia da Universidade de São Paulo (MZUSP), and National Museum of Natural History/Smithsonian Institution (USNM). 


\section{RESULTS}

Odontocharacidium varii, new species

urn:lsid:zoobank.org:act:44171E14-9E40-4960-ACAE-26896C655D3F

(Fig. 1; Tab. 1)

Odontocharacidium aphanes (not Weitzman, Kanazawa, 1977). -Buckup, 1993a:30541 (phylogenetic study of Characidiinae). - Buckup, 1993b:136 (description of Odontocharacidium; distribution). -Buckup, 2003:93 (Checklist; occurrence in Venezuela). -Buckup, van der Sleen, 2018:147 (Field guide; distribution).

Holotype. MHNLS 26156, 14.7 mm SL, Venezuela, Río Negro Municipality, Río Orinoco, Caño Chola, where it crosses the road from San Carlos de Río Negro to Solano, $1^{\circ} 58^{\prime} 00 ” N 67^{\circ} 00^{\prime} 00 ” W, 11$ Apr 1985, R.P. Vari.

Paratypes. All from Venezuela, Amazonas: ANSP 161317, 8, 14.3-15.8 mm SL, Venezuela, Amazonas, Cano Caño entering eastern side of Río Casiquiare ca. $7.0 \mathrm{~km}$ approx. downstream from mouth of Río Pamoni, $2^{\circ} 48^{\prime} 00$ ”N 65 58'00”W, 20 Mar 1987, B. Chernoff, S.W.G. Lopes, J. Fernandez, O. Castillo, M.E Antonio. FMNH 105971, 4, 12.7-12.8 mm SL, Venezuela, Território Federal Amazonas [Currently Estado Amazonas], Caño Curcutito about. $1 \mathrm{~km}$ upstream mouth in Río Autana, 443’48”N 67³7'12”W, 11 Feb 1992, B. Chernoff, A. Machado-Allison, J. A Wheeler, J. Fernandez, N. M. Gotschall. USNM 270149, 21, 14.1-16.6 mm SL (2 c\&s), 14.8-15.8 $\mathrm{mm}$ SL, collected with holotype.

Diagnosis. Odontocharacidium varii differs from $O$. aphanes by the presence of the antorbital ( $v s$. antorbital absent); the presence of the supraorbital laterosensory canal ( $v s$. canal absent); the presence of postcleithrum 1 ( $v s$. postcleithrum 1 absent); the presence of conspicuous bars extending ventrally to the middle portion of the body ( $v s$. bars restricted to the dorsal portion of the body); and the presence of two dark round blotches located at the tip of caudal peduncle ( $v$ s. blotches absent).

Description. Morphometric data for the holotype and paratypes, Tab.1. Body short, relatively compressed. Dorsal profile convex from snout tip to dorsal-fin terminus, slightly concave or nearly straight from that point to insertion of anteriormost dorsal caudal-fin procurrent rays. Ventral profile convex from lower lip to pelvic-fin insertion, moderately convex from that point to anal-fin origin, becoming slightly concave from that point to insertion of first ventral procurrent caudal-fin ray.

Mouth small, terminal. Teeth on both jaws conical, Fig. 2. Premaxilla with single row of 9(1) or 10(1) teeth decreasing in size laterally. Maxilla reaching vertical through anterior margin of orbit. Maxilla with 9(1) or 10(1) teeth along entire ventral edge, Fig. 2. Dentary with two series of teeth, outer series with 8(2), inner series with 9(1) or 12(1). Ectopterygoid teeth 6(1) or 7(1). Endopterygoid edentulous. Nostrils round distinctly separated by fleshy bridge without dermal flaps. Posterior nostril closer to orbit and 
TABLE 1 I Morphometrics of Odontocharacidium varii. Number of individuals (20), mean, minimum (Min), maximum (Max) and standard deviation (SD) include values of the holotype.

\begin{tabular}{|c|c|c|c|c|c|}
\hline & Holotype & Min & $\operatorname{Max}$ & Mean & SD \\
\hline Total length (mm) & 18.6 & 17.5 & 19.8 & 18.7 & 0.5 \\
\hline Standard length (mm) & 14.7 & 14.1 & 16.7 & 15.1 & 0.6 \\
\hline Head length (mm) & 4.5 & 4.0 & 5.1 & 4.5 & 0.3 \\
\hline \multicolumn{6}{|c|}{ Percentage of SL } \\
\hline Body depth at dorsal-fin origin & 23.0 & 22.0 & 25.9 & 23.3 & 1.0 \\
\hline Body depth at anal-fin origin & 12.0 & 11.8 & 14.7 & 13.5 & 0.8 \\
\hline Body depth at caudal peduncle & 9.9 & 7.7 & 15.9 & 9.1 & 1.7 \\
\hline Head length & 30.8 & 27.9 & 31.4 & 30.0 & 1.1 \\
\hline Preanal distance & 75.0 & 72.8 & 77.4 & 74.7 & 1.1 \\
\hline Predorsal distance & 49.8 & 47.6 & 90.6 & 49.0 & 0.7 \\
\hline Prepectoral distance & 33.0 & 29.9 & 33.5 & 31.5 & 1.1 \\
\hline Prepelvic distance & 53.2 & 48.7 & 53.2 & 51.1 & 1.3 \\
\hline Anal-apex distance & 88.5 & 86.7 & 90.6 & 88.7 & 1.1 \\
\hline Body width & 14.0 & 11.9 & 15.5 & 13.7 & 0.9 \\
\hline \multicolumn{6}{|c|}{ Percentage of $\mathrm{HL}$} \\
\hline Snout length & 18.9 & 18.7 & 23.8 & 20.4 & 1.3 \\
\hline Orbital diameter & 37.2 & 35.2 & 42.0 & 38.6 & 1.8 \\
\hline Cheek depth & 7.2 & 4.3 & 9.8 & 7.2 & 1.4 \\
\hline Anterior naris-orbit & 6.2 & 4.3 & 8.7 & 6.3 & 1.1 \\
\hline Posterior naris-orbit & 5.7 & 5.7 & 15.3 & 10.5 & 2.1 \\
\hline Snout-maxillary tip & 20.0 & 15.6 & 25.9 & 19.9 & 2.5 \\
\hline Interorbital distance & 28.4 & 21.4 & 35.1 & 27.5 & 3.1 \\
\hline
\end{tabular}

slightly larger than anterior nostril. Small cranial fontanel bordered by supraoccipital, parietal and frontal. Branchiostegal rays 4(2);3(2) in the anterior ceratohyal, and 1(2) between the anterior ceratohyal and posterior ceratohyal. Antorbital present. Parietal branch of supraorbital laterosensory canal present.

Scales cycloid. Lateral line longitudinal series with 29(1), 30*(5), 31(7), 32(3) or 33(2) scales, of which $4(6), 5^{\star}(8)$ or $6(2)$ are perforated. Longitudinal series above lateral line $3(18)$ or $4^{\star}(2)$; and $4^{\star}(17)$ or $5(2)$ below. Predorsal scales $6(1), 7^{\star}(10)$ or $8(9)$. Isthmus completely scaled. Circumpeduncular scales $12^{\star}(20)$.

Pectoral-fin total rays $7(1), 8(5)$ or $9^{\star}(14)$, second and third rays longest. Tip of adpressed pectoral fin not reaching pelvic-fin origin. Postcleitrum 1 present. Pelvicfin total rays $8(3), 9^{\star}(14)$ or $10(2)$; first, second and third rays longest. Longest pelvicfin rays reaching vertical through anal-fin origin. Supraneurals $4(2)$, anterior to neural spines of vertebral centra 5-8(2). Dorsal-fin rays ii, $9^{\star}(22)$; second and third rays longest; first pterygiophore anterior to neural spine of centrum 9(2). Adipose fin present or absent, present in holotype. Anal-fin rays ii,5(5), ii, $6^{\star}(6)$ or ii,7(9); third and fourth rays longest; first pterygiophore anterior to haemal spine of centrum 20(1) or 21(1). Caudalfin principal rays 10/8(1) or 10/9 (21). Hypural 6 present. Precaudal vertebrae $17(2)$, caudal 15(2); total vertebrae 32(2). 


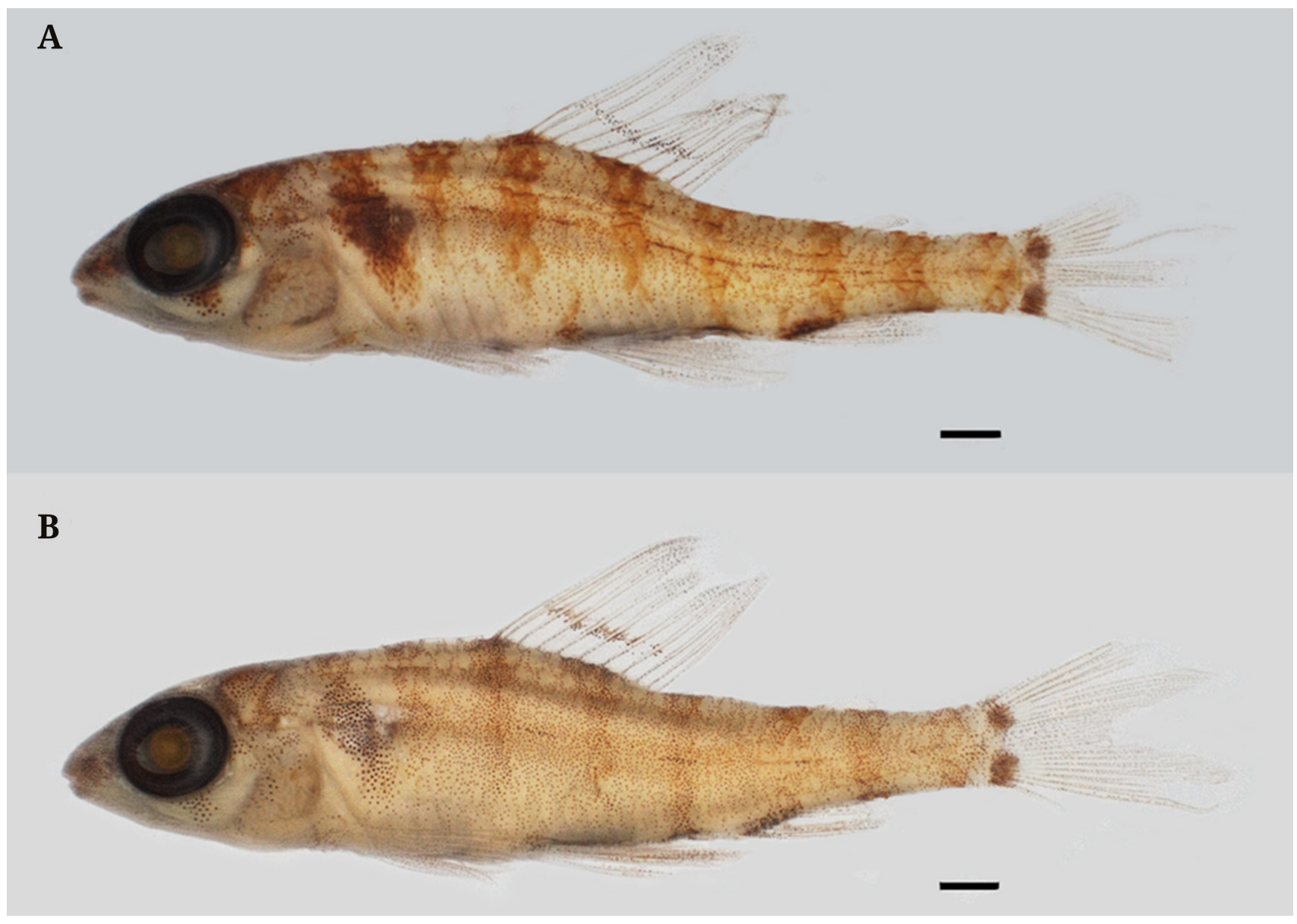

FIGURE 1 I Odontocharacidium varii, new species, A. Holotype, MHNLS 26156, 14.7 mm SL, Venezuela, Río Negro Municipality, Río Orinoco; Paratype, USNM 270149, 14.3 mm SL, Venezuela, Río Negro Municipality, Río Orinoco. Scale bar = $1 \mathrm{~mm}$.

Coloration in alcohol. Background color of head and body pale yellow. Dark brown chromatophores scattered on sides of head. Chromatophores conspicuously concentrated on upper lip, with area between nostrils forming diffuse band. Small concentration of chromatophores from lower lip to near terminus of maxilla. Concentration of chromatophores forming dark triangular suborbital blotch. Dorsal profile of head and posterior margin of orbit with scattered chromatophores forming light brown pigmentation. Dorsal portion of head conspicuously more pigmented than lateral portions. Opercular membrane hyaline.

Humeral blotch present, conspicuous. Vertical bars on dorsal portion of body 6(2), $7(8), 8^{\star}(7)$ or $9(3)$; bars anterior to insertion of dorsal fin $2^{\star}(19)$ or $3(1) ; 2^{\star}(20)$ along dorsal-fin base; 3(1), $4^{\star}(16)$ or 5(3) between dorsal-fin terminus and distal tip of caudal peduncle. Bars reaching beyond the midline portion of the body ventrally usually between pelvic-fin and anal-fin origins, with posterior most four bars reaching ventral portion of body. Horizontal septum intermittently pigmented, forming series of thin, dark dashes from pectoral girdle to near tip of caudal peduncle. Ventral portion with 


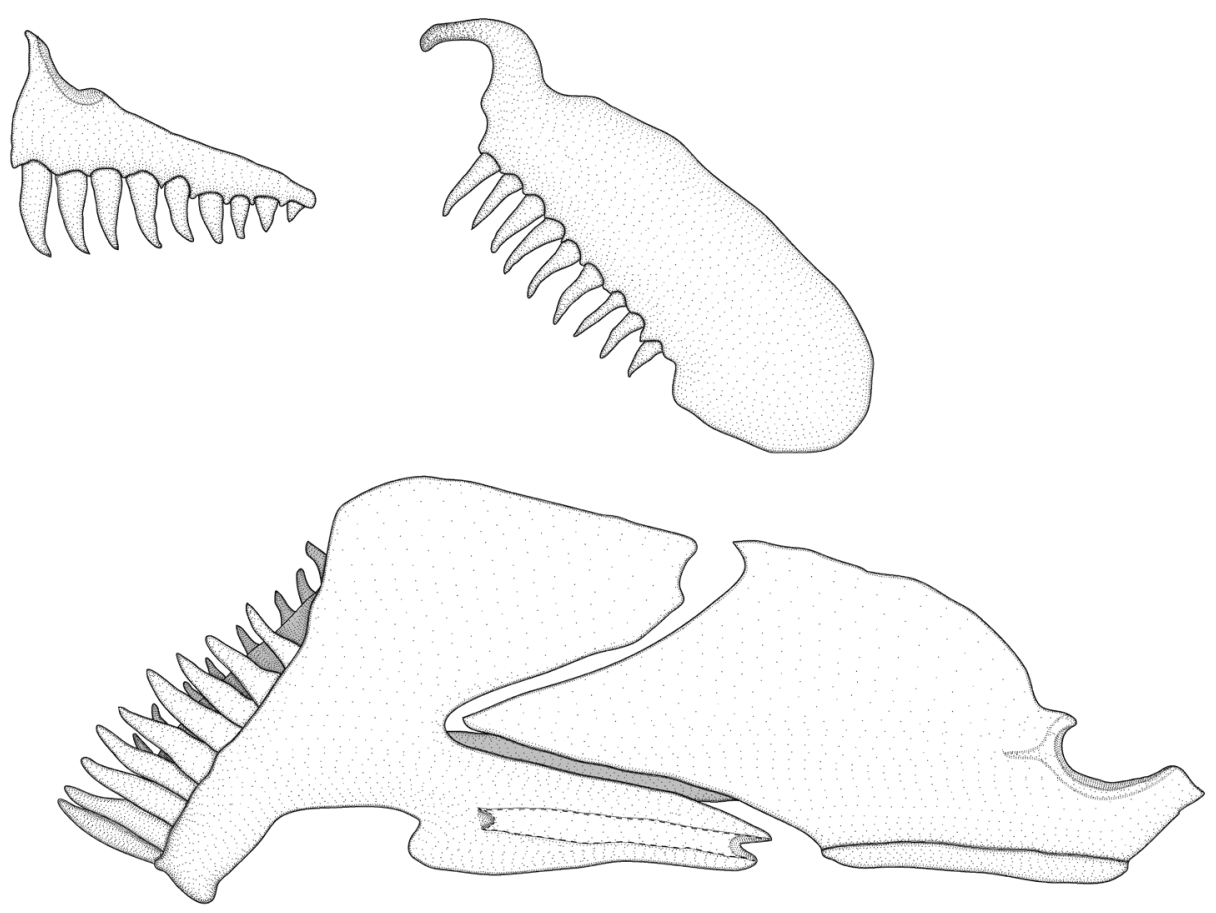

FIGURE 2 I Odontocharacidium varii, new species, USNM 270149, paratype, $15.8 \mathrm{~mm}$ SL, Venezuela, Río Negro Municipality, Río Orinoco. Lateral view of mandibular arch and dentition, flipped right side, anterior to left.

concentration of chromatophores on mid-ventral scales forming three thin dark bands at pelvic-fin origin, near anus and at anal-fin base. Caudal peduncle with two dark round blotches at base of each caudal-fin lobe. Pectoral, pelvic, anal and caudal fins hyaline with scattered chromatophores at distal tips. Dorsal fin with concentration of chromatophores forming two discrete horizontal bands, one at middle of in rays and the other at distal tip.

Sexual dimorphism. Dissection of paratypes of Odontocharacidium varii for gonad inspection failed to unambiguously determine sex of available specimens, as gonads of all examined specimens seemed to be immature or in resting stages. Additionally, no distinguishable external secondary sexually dimorphic characters were observed in those specimens.

Geographical distribution. Odontocharacidium varii is known from the upper portion of the Río Orinoco, Fig. 3.

Etymology. The specific epithet is in honor to Richard P. Vari, first collector of the new species and constant professional inspiration to the authors. A noun in genitive.

Conservation status. Odontocharacidium varii is known from three different localities in the upper Río Orinoco basin. Although none of the sampling sites is within preservation areas, those appear to be well preserved. Besides, there are several national 


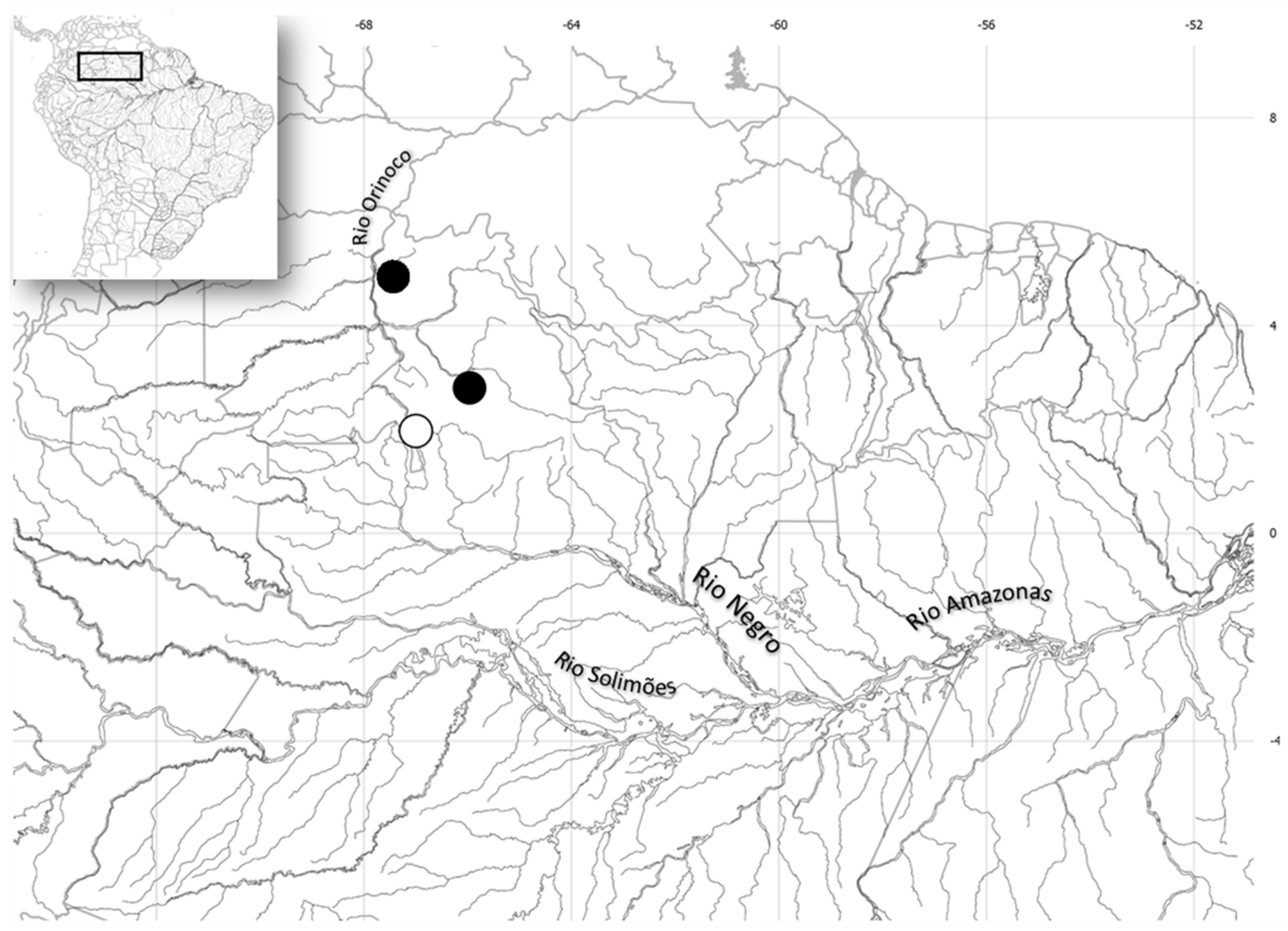

FIGURE 3 I Map of geographical distribution of Odontocharacidium varii (circles). Type-locality represented by the same symbol in white color.

parks and indigenous areas surrounding the known area of occurrence of the species, suggesting the lack of significant threats to the conservation of the species. Therefore, Odontocharacidium varii can be classified herein as a Least Concern (LC) species according to the International Union for Conservation of Nature (IUCN) categories and criteria (IUCN, 2019).

Remarks. Odontocharacidium varii present a slight variation of color pattern, with some specimens having it more pronounced than others. The bands, bars and the humeral blotch can vary in intensity among specimens from the same lot, Fig. 1. It is unclear at this moment if this phenomenon is indicative of intraspecific variation or coloration fading of the specimens. Nevertheless, both limits of the variation range allow unambiguous distinction between specimens of O. varii from O. aphanes.

Comparative material examined. Brazil, Rio Negro: MZUSP 12978, 1, $13.4 \mathrm{~mm}$ SL (holotype of Odontocharacidium aphanes Weitzman \& Kanazawa, 1977). MZUSP 12979, 3, 11.4-13.0 mm SL (paratypes of Odontocharacidium aphanes). MZUSP 109657, 
2, 12.3-11.8 mm SL. MPEG 25491, 2, 14.6-16.2 mm SL. Rio Branco: INPA 39429, 2, 13.1-12.4 mm SL. MZUSP 113270, 3, 10.1-10.3 mm SL. MZUSP 113665, 36, $10.8-$ 13.3 mm SL. LBP 15115, 12, 14.1-15.9 mm SL, 1 c\&s, 14.6 mm SL. LBP 15114, 8, 15-16.1 mm SL, 1 c\&s, 14.7 mm SL.

\section{DISCUSSION}

The close relationship between Odontocharacidium varii and O. aphanes is proposed herein as both species share most diagnostics characters hypothesized by Buckup (1993b) as defining the genus: 1) absence of the posttemporal; 2) absence of the the supratemporal sensory canal; 3) absence of the pterotic sensory canal, and 4) pterotic, parietal and sphenotic lacking dermal portions between the semicircular canals, with the posttemporal fossa limited anteriorly by the sphenotic; 5) absence of postcleithrum 1 (Buckup 1993b). Conversely, unlike O. aphanes, the specimens of Odontocharacidium varii examined herein present a bilaterally symmetric postcleithrum 1 , an antorbital and the parietal branch of supraorbital laterosensory canal, conditions absent in O. aphanes. The sharing of four out of five exclusive characters defining Odontocharacidium justifies not only the inclusion of the species described herein in the genus, but also to rediagnose the genus, based only on the absence of the posttemporal, the absence of the the supratemporal sensory canal, the absence of the pterotic sensory canal, and the lack of dermal portions on the pterotic, parietal and sphenotic between the semicircular canals, with the posttemporal fossa limited anteriorly by the sphenotic.

The diagnostic features of Odontocharacidium proposed by Buckup (1993b) and reviewed herein seem to represent developmental truncations, associated to the miniaturization process, which usually leads to losses and simplifications of dermal bones (i.e. posttemporal and postcleithra) or dermal portions of composite bones (i.e. pterotic and sphenotic) (Britz, Conway, 2009; Britz et al., 2009; Toledo-Piza et al., 2014; Mattox et al., 2016). Although no mature specimens of Odontocharacidium varii were detected in the present study, none of the 34 representatives of the species examined herein is larger than $17 \mathrm{~mm} \mathrm{SL}$, suggesting a size range similar to that of $O$. aphanes for O. varii. The new species would, therefore, fit the criteria established by Weitzman, Vari (1988) to consider this species a miniature, bringing the number of miniaturized crenuchids to 17 (Toledo-Piza et al., 2014; Mendonça, Netto-Ferreira 2015).

Although Buckup (1993a) considered the absence of the parietal branch of the supraorbital canal as a synapomorphy for the clade including Elachocharax, Microcharacidium and Odontocharacidium (EMO), representatives of the new species described herein present a small bony tube branching from the supraorbital laterosensory canal, topologically similar to that illustrated by Buckup (1993c) for Characidium fasciatum Reinhardt, and by Weitzman (1962) for Brycon meeki Eigenmann, Hildebrand, and attributed as the parietal branch of the supraorbital canal. Representatives of $O$. aphanes and species of Microcharacidium, on the other hand, indeed lack any branching on the supraorbital canal as described by that author, and the presence of that condition in O. varii may be considered a reversal. Likewise, the pair of dark blotches at the base of each caudal-fin lobe, also hypothesized as synapomorphic of the aforementioned clade containing the three genera seems to have been secondarily lost in Odontocharacidium 
aphanes. Buckup (1993a) considered this character as present in O. aphanes, but in fact, such interpretation was actually based on specimens of the lot USNM 270149, herein recognized as Odontocharacidium varii (see synonymy list).

Weitzman, Kanazawa (1977) observed a conspicuous variability in the number of maxillary teeth (9 to 17), when describing Odontocharacidium aphanes. The examination of specimens of $O$. aphanes herein resulted in a slightly greater variation (3 to 15), although no specimens with more than 15 teeth were found. Within that variation, some specimens seem to present consistently teeth restricted to the anterior portion of the maxilla, whereas other specimens usually have teeth covering the entire ventral surface of the bone. Unlike O. aphanes, all examined representatives of O. varii have teeth along the entire ventral edge of the maxilla, Fig. 2. A similar condition was described associated with sexual dimorphism in Copella and Pyrrhulina members of the Lebiasinidae (Netto-Ferreira, Marinho, 2013; Marinho, Menezes, 2017; Vieira, NettoFerreira, 2019).

To this moment, Odontocharacidium varii had been confused with O. aphanes in collections and by Buckup (1993a,b), who examined the specimens from Caño Chola (USNM 270149). Such misidentification may have been induced by the distinctive overall morphology of Odontocharacidium among Characidiinae, besides the diminutive size of the specimens, which can be considered an additional difficulty in detecting the variation among different populations or species in the genus. Considering the minute size of the representatives of the genus, and the lack of taxonomic studies subsequent to those of Buckup (1993a), it is likely that the species richness in Odontocharacidium and other miniature Crenuchidae may be considerably underestimated and pending formal description, as was recently observed by (Toledo-Piza et al., 2014; Mattox et al., 2016) for the heterocharacin Priocharax Weitzman, Vari.

\section{ACKNOWLEDGMENTS}

Authors are thankful to Mark Sabaj and Mariangeles Arce (ANSP), Caleb McMahan and Susan Mochel (FMNH), Lúcia Rapp Py-Daniel (INPA), Claudio Oliveira (LBP), Carlos Lucena and Margarete Lucena (MCP), Oscar Lasso-Alcalá (MHNLS), Wolmar Wosiacki (MPEG), Alessio Datovo (MZUSP), Jeffrey Williams (USNM), for support during visits and loan of specimens. Authors are also thankful to Alberto Akama (MPEG), Claudio Oliveira (UNESP), Luiz Malabarba (UFRGS) and Wolmar Wosiacki (MPEG) for providing space and facilities during early stages of this project. This paper is part of the Masters dissertation of EKQR, with the financial support of master's degree fellowship by $\mathrm{CNPq}$ (Conselho Nacional de Desenvolvimento Científico e Tecnológico; proc. $\mathrm{n}^{\circ}$ 130950/2016-5), at the Programa de Pós-Graduação em Zoologia UFPA/MPEG. 


\section{REFERENCES}

- Britz R, Conway KW, Rüber L. Spectacular morphological novelty in a miniature cyprinid fish, Danionella dracula n. sp. Proc R Soc B. 2009; 276(1665):2179-86.

- Britz R, Conway KW. Osteology of Paedocypris, a miniature and highly developmentally truncated fish (Teleostei: Ostariophysi: Cyprinidae). J Morphol. 2009; 270(4):389-412. https://doi.org/10.1002/ jmor.10698

- Buckup PA, van der Sleen P. Family Crenuchidae-South American darters. In: van der Sleen P, Albert, JS, editors. Field guide to the fishes of the Amazon, Orinoco, and Guianas. New Jersey: Princeton University Press; 2018. p.142-48.

- Buckup PA. Family Crenuchidae (South American Darters). In: Reis RE, Kullander SO, Ferraris CJJ, editors. Check list of the freshwater fishes of South and Central America. Porto Alegre: Edipucrs; 2003. p.87-95.

- Buckup PA. Phylogenetic interrelationships and reductive evolution in Neotropical characidiin fishes (Characiformes, Ostariophysi). Cladistics. 1993a; 9(3):305-41. https://doi. org/10.1111/j.1096-0031.1993.tb00227.x

- Buckup PA. Review of the characidiin fishes (Teleostei: Characiformes), with descriptions of four new genera and ten new species. Ichthyol Explor Fres. 1993b; 4(2):97-154.

- Buckup PA. The monophyly of the Characidiinae, a Neotropical group of characiform fishes (Teleostei: Ostariophysi). Zool J Linnean Soc. 1993c; 108:225-45.

- Fricke R, Eschmeyer WN, Fong JD. Species by family/subfamily in the Catalog of Fishe [Internet]. San Francisco: California Academy of Sciences; 2020. Avaible from: http://researcharchive. calacademy.org/research/ichthyology/ catalog/SpeciesByFamily.asp

- International Union for Conservation of Nature (IUCN). Standards and Petitions Subcommittee. Guidelines for Using the IUCN Red List Categories and Criteria. Version 14 [Internet]. 2019. Available from: https://nc.iucnredlist.org/redlist/content/ attachment_files/RedListGuidelines.pdf
- Marinho MMF, Menezes NA. Taxonomic review of Copella (Characiformes: Lebiasinidae) with an identification key for the species. PLoS One. 2017; 12(8):e0183069. https://doi.org/10.1371/ journal.pone.0183069

- Mattox GM, Britz R, Toledo-Piza M. Osteology of Priocharax and remarkable developmental truncation in a miniature Amazonian fish (Teleostei: Characiformes: Characidae). J Morphol. 2016; 277(1):65-85. https://doi.org/10.1002/jmor.20477

- Mendonça MB, Netto-Ferreira AL. New Species of Characidium (Characiformes: Crenuchidae) From the Rio Tapajós and Rio Xingu Drainages, Pará, Brazil. Zootaxa. 2015; 4021(1):187-94. http://dx.doi. org/10.11646/zootaxa.4021.1.9

- Netto-Ferreira AL, Marinho MMF. New species of Pyrrhulina (Ostariophysi: Characiformes: Lebiasinidae) from the Brazilian Shield, with comments on a putative monophyletic group of species in the genus. Zootaxa. 2013; 3664(3):369-76. http://dx.doi.org/10.11646/zootaxa.3664.3.7

- Taylor WR, Van Dyke GC. Revised procedures for staining and clearing small fishes and other vertebrates for bone and cartilage study. Cybium. 1985; 9(2):107-19. Avaible from: http://sfi-cybium.fr/en/ node/2423

- Toledo-Piza M, Mattox GM, Britz R. Priocharax nanus, a new miniature characid from the rio Negro, Amazon basin (Ostariophysi: Characiformes), with an updated list of miniature Neotropical freshwater fishes. Neotrop Ichthyol. 2014; 12(2):229-46. http://dx.doi. org/10.1590/1982-0224-20130171

- Vieira LS, Netto-Ferreira AL. New species of Pyrrhulina (Teleostei: Characiformes: Lebiasinidae) from the eastern Amazon, Pará, Brazil. Neotrop Ichthyol. 2019; 17(2): e190013. http://dx.doi.org/10.1590/19820224-20190013

- Weitzman SH, Kanazawa RH. A new species of pygmy characoid fish from the Rio Negro and Rio Amazonas, South America (Teleostei: Characidae). P Biol Soc Wash. 1977; 90(1):149-60. Avaible from: https://www.biodiversitylibrary.org/ page/39057897\#page/173/mode/1up 


\section{Neotropical |chthyology}

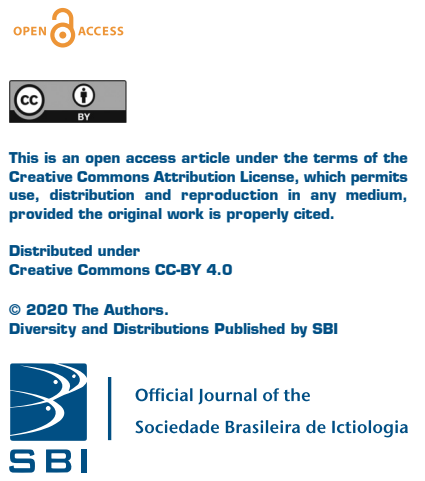

- Weitzman SH, Vari RP. Miniaturization in South American freshwater fishes; an overview and discussion. P Biol Soc Wash. 1988; 101(2):444-65. Avaible from: https://ia800207.us.archive.org/31/items/ biostor-77854/biostor-77854.pdf
- Weitzman SH. The osteology of Brycon meeki, a generalized characid fish, with an osteological definition of the family. Stanford Ichth Bull. 1962; 8:1-77.

\section{AUTHOR'S CONTRIBUTION 주}

Elizabeth Kathleen de Queiroz Rodrigues: Conceptualization, Data curation, Formal analysis, Funding acquisition, Investigation, Methodology, Project administration, Resources, Software, Validation, Writingoriginal draft, Writing-review \& editing.

Andre Luiz Netto-Ferreira: Conceptualization, Data curation, Formal analysis, Funding acquisition, Investigation, Methodology, Project administration, Resources, Supervision, Validation, Writing-review \& editing.

\section{ETHICAL STATEMENT}

Not applicable.

\section{COMPETING INTERESTS}

The authors declare no competing interests.

\section{HOW TO CITE THIS ARTICLE}

- Rodrigues EKQ, Netto-Ferreira AL. A new miniature species of Odontocharacidium (Characiformes: Crenuchidae) from the Río Orinoco basin, Venezuela. Neotrop Ichthyol. 2020; 18(2):e190008. https://doi.org/10.1590/1982-0224-2019-0008 